\title{
Las Casas e a escravidão na América Espanhola
}

\section{Maria Alice Messias Conforti de Carvalho *}

DOI: 10.11606/issn.2318-8855.v10i1p441-456

Resumo: Este artigo tem o objetivo de analisar a delicada relação do frei dominicano Bartolomé de Las Casas com a escravidão na América Espanhola, mostrando sua transição de um padre-encomendero para um porta-voz da luta pela emancipação indígena nas colônias espanholas e, ao mesmo tempo, a contraditória relação do frade tanto com a escravização destes povos nativos, quanto dos povos africanos. Para isso, o texto será escrito no formato expositivo-argumentativo, provendo uma breve contextualização do momento histórico que leva ao surgimento de Las Casas e sua decisão de passar a defender a "causa indígena". A parte argumentativa virá a partir do debate por trás da representação da figura de Las Casas,e, até o final do artigo, se mostrará a concepção do autor do presente artigo sobre esta questão, evidenciando que a idealização de uma figura histórica, sobretudo de um eclesiástico em plena América Colonial, acaba por desconsiderar muitos fatores não tão "heroicos", mas mesmo assim não sem importância.

Palavras-Chave: Las Casas; escravidão; América Espanhola 


\section{artigos}

\section{Maria Alice Messias Conforti de Carvalho}

\section{Introdução}

“Os espanhóis não procuram outra cousa senão mandar e ser adorados pelos índios como senhores. (...) Os espanhóis impedem deliberadamente e abertamente que o Evangelho seja ensinado aos índios e que eles se tornem cristãos." (Las Casas, 1984).

Muito se pode extrair desta citação de Bartolomé de Las Casas retirada de seu livro Brevíssima Relação da Destruição das Índias.

A maneira com que o frade parece separar a si mesmo dos espanhóis não é um posicionamento isolado individual, mas sim explicita a situação em que estava a relação entre Igreja Católica e a Coroa Espanhola na época.

Trabalhando conjuntamente na luta territorial na Península Ibérica contra a expansão islâmica, o Estado percebeu a importância da religião católica para unificar os povos colonizados e assim centralizar sua lealdade à Coroa. Esta lógica foi então aplicada ao Novo Mundo. As duas instituições trabalhavam de tal forma que, segundo PEREZ (1947, p.395), enquanto o poder laico guerreava, o eclesiástico colonizava a terra.

Esta relação, embora de primeiro momento pudesse parecer ser de benefício mútuo, na verdade acaba por ser um empecilho para a Igreja, que, sem condições de fazer missões de evangelização por conta própria, torna-se controlada pela Coroa em um nível discrepante de qualquer outro anteriormente. A Coroa passa a decidir quanto ao envio de religiosos, intercepta a comunicação entre Roma e Índias, paga os salários de eclesiásticos e constrói catedrais, igrejas e mosteiros com os dízimos (BARNADAS, 1984).

Esta submissão involuntária da Igreja chega a um ponto culminante quando ela 


\section{artigos}

\section{Las Casas e a escravidão na América Espanhola}

resolve pegar para si a causa indígena, denunciando os atos de crueldade e quase escravidão pelo qual os povos nativos eram submetidos pelos espanhóis nas encomiendas?

Mas por que, com seu histórico de torturas, teria a Igreja adotado uma causa humanitária como esta?

Possivelmente porque se deu preferência ao envio, para as colônias, de um tipo de frade chamado de "reformado" ou "observante", que mostrava entusiasmo pela missão de pregação, havia feito votos de pobreza e não tinha pretensões senhoriais (BARNADAS, 1984). Eram padres que não viam os indígenas como ferramentas de trabalho para interesses econômicos.

É neste perfil que se encaixa o padre Antônio de Montesinos, responsável pelo sermão do último domingo de novembro de 1511 e que daria início a esta luta eclesiástica pela causa indígena, além de inspirar o então encomendero Bartolomé de Las Casas a eventualmente abrir mão de suas posses e se juntar à causa (BUENO, 1984).

É importante notar, no entanto, que Montesinos, Las Casas, e todos como eles, eram, sobretudo, membros do clero e, como mostra a citação que dá início ao artigo, tinham por objetivo principal não só a libertação indígena contra o sistema abusivo de encomiendas, mas também a conversão destes povos nativos à fé cristã.

Isto explica outra razão pela qual a "questão" indígena foi adotada pelos

\footnotetext{
${ }^{1}$ As encomiendas foram direitos temporários de coletar tributos de índios como recompensa pela conquista (Batchelder, R., \& Sanchez, 2013, p. 45). Cada encomendero tinha seu número de indígenas que pagavam pelo "serviço" de serem incorporados aos costumes e moldes europeus. O pagamento muitas vezes era por meio do trabalho compulsório, o que colocava os indígenas sob condições análogas a escravidão, submetidos às vontades e maus tratos de seus encomenderos.
} 


\section{artigos}

\section{Maria Alice Messias Conforti de Carvalho}

religiosos: a visão dos nativos como seres puros e intocados pelo mal ou pecado, prontos para serem modelados à religião e ao estilo de vida católico. Como descreve o próprio Las Casas (1984), os índios eram criaturas “dóceis (...), muito aptos a receber nossa santa Fé Católica e a serem instruídos em bons e virtuosos costumes.".

\section{O trabalho indígena pelos indígenas e suas variáveis}

Ao transacionar de um encomendero para um reformista, Las Casas logo começou uma campanha contra os antigos companheiros colonizadores apelando para a Coroa, ferramenta que ele usaria constantemente ao longo de sua vida.

Considerando-se representantes do rei no Novo Mundo, os colonizadores defendiam as encomiendas por serem, segundo eles, a melhor forma de conter o instinto animalesco dos índios, enquanto Las Casas e seus companheiros reformistas consideravam que estes na verdade realizavam apenas as próprias vontades e passavam por cima da soberania absoluta da Coroa no território americano, usando do nome do rei para justificar atos de tortura para com os indígenas.

Os reformistas defendiam como alternativa o fim das encomiendas e o "uso" dos indígenas pela Coroa espanhola, julgando que esta saberia tratá-los de uma maneira menos cruel e permitiria uma conversão humanizada dos nativos. É importante notar como a total independência dos povos e a devolução de seu território nunca foi uma pauta considerada por estes autodeclarados defensores dos índios. Segundo CASTRO (2007, p.67), o debate era apenas entre o colonialismo dos encomenderos ou o imperialismo da Coroa e dos reformistas.

Las Casas também não demonstrava nenhum descontentamento com a exploração das terras e de suas riquezas pela Coroa, muito pelo contrário. Ele chegou a usar como argumento ao rei, em favor do fim das encomiendas, o grande benefício 


\section{artigos}

\section{Las Casas e a escravidão na América Espanhola}

econômico que se daria se o trabalho indígena fosse usufruído de forma direta pela Coroa.

Las Casas e seus companheiros não pareciam também perceber a violência que a conversão à religião e aos costumes católicos infligia aos nativos, por mais pacífica que se tentasse fazê-la. Em relação a um episódio trágico, em que um grupo de índios cometeu suicídio em massa para que não fossem convertidos, o reformista explicou que isso aconteceu por causa do impacto das atrocidades feitas pelos colonizadores, que os fez associar a crueldade que presenciaram à religião de seus dominadores.

Esta alienação para o fato de que a violência vem em outras formas além da física, (aculturação, exploração de terras etc), bem como sua vontade de "mediar" o interesse dos indígenas com os da Coroa, se tornam peça-chave para entender a contradição existente em Las Casas na sua luta pelos povos do Novo Mundo.

Isto se evidencia no seu "Memorial de Remedios", de 1516, em que Las Casas apresenta catorze remédios (propostas) para que a Coroa consiga melhorar a situação dos indígenas nas Américas, fazendo exigências como o fim do trabalho comendero, seguido de um tempo de descanso para que se tornem mais fortes e mais eficientes para o trabalho (primeiro remédio); e a incorporação efetiva e imutável dos nativos à Coroa como "súditos e vassalos livres" (LAS CASAS, 1984, p. 125).

Em 1518, Las Casas inicia um de seus projetos mais marcantes para sua construção enquanto reformista e "voz dos índios". O frade propõe à Coroa um plano de colonização de terras indígenas usando apenas fazendeiros castellanos e membros do clero, com a entrada proibida de encomienderos, propondo assim um ambiente em que os nativos seriam ensinados a vida rural. Espanhóis, indígenas e 


\section{artigos}

\section{Maria Alice Messias Conforti de Carvalho}

dominicanos viveriam, assim, em harmonia. Ele também menciona, como já se deve imaginar, os ganhos econômicos que o projeto trará à Espanha.

O rei lhe concede então uma terra, conhecida como Cumaná, na costa da Venezuela para a realização deste projeto. Mas as coisas logo começam a dar errado quando encomenderos da região boicotam o plano de todas as maneiras possíveis, se recusando a ceder seus fazendeiros e invadindo as terras para caçar indígenas com o objetivo de escravizá-los, ajudados por soldados que estavam encarregados de proteger a região. O projeto utópico logo fracassa, com os nativos se rebelando e matando seis pessoas.

Após o fim de Cumaná, Las Casas se mantém recluso durante alguns anos até voltar a público com o notório caso do cacique Enriquillo. Indígena educado em um monastério franciscano, o cacique se rebelou contra o encomendero para o qual trabalhava, após este abusar sexualmente de sua esposa. Enriquillo fugiu para as montanhas e lá, junto com cerca de trezentos rebeldes, resistiu durante cerca de treze anos a todos os avanços espanhóis, acabando por desistir por exaustão.

A relação de Las Casas com o caso de novo demonstra seu conturbado vínculo com a defesa dos indígenas. $\mathrm{O}$ frade alega ter mantido contato durante cerca de um mês com o cacique e contribuído para sua decisão de se entregar de maneira pacífica. No entanto, de acordo com Castro (2007, p. 94-95), esta correspondência parece ter sido muito mais a serviço próprio e da Igreja, já que Las Casas usou do ocorrido para retratar Enriquillo como um símbolo de gentileza e pacificidade cristã, ignorando sua luta armada contra os colonizadores. Mais uma vez, a figura do indígena é retratada por Las Casas como sujeito passivo, isento de qualquer poder de autodefesa.

Em 1537, Las Casas, impulsionado pelas provocações de encomienderos locais, 


\section{artigos}

\section{Las Casas e a escravidão na América Espanhola}

começa seu mais novo projeto de conversão de indígenas, em uma área chamada Tuzulután, conhecida como "terra da guerra". Lentamente, o frade e sua equipe conseguiram, por meio de trocas de presentes e calculados processos de avanço no território, conquistar os caciques da área e convertê-los, bem como seus povos nativos. Ele finalmente consegue levar para a prática sua teoria da colonização "pacífica".

\section{A escravidão africana}

Pouco se sabe sobre a posição de Las Casas quanto à escravidão dos africanos. Já em sua época havia intelectuais que debatiam sobre o tema e interpretavam suas inclinações e influências quanto ao tópico.

Entre aproximadamente 1601 e 1615, Herrero y Tordesillas escrevem que Las Casas não só apoiava o tráfico negreiro às Índias, como foi muito influente na decisão, e ainda usou essa influência para avançar o projeto na corte flamenca (SANCHÉZGODOY, 2009, p. 4). Já entre 1730 e 1731, o jesuíta Charlevoix oferece uma visão menos acusatória, defendendo que o dominicano possuía um cuidado especial com os indígenas e que por isso fez a sugestão para que os substituíssem por africanos bem como por lavradores (2009, p. 5). Em sua concepção, o foco de Las Casas era a libertação indígena, e não em quem os substituiria.

Essa última concepção parece ser a mais correta ao analisar o Memorial de Remédios, em que o frade escreve, no décimo primeiro remédio, que "em vez dos índios que havia de ter [em] as ditas comunidades, sustente em cada uma vinte negros ou outros escravos nas $\operatorname{minas}^{\prime 2}$ (LAS CASAS, 1984, p. 125). Em outro ponto do

\footnotetext{
${ }^{2}$ No original: "en lugar de los indios que había de tener [en] las dichas comunidades, sustente en cada una veinte negros o otros esclavos en las minas"
} 


\section{artigos}

\section{Maria Alice Messias Conforti de Carvalho}

texto, segundo Sanchéz-Godoy, Las Casas explicitamente diz que tais escravos podem ser negros ou brancos de Castilla. (SANCHÉZ-GODOY, 2009, p. 77).

Las Casas volta a falar sobre os escravos africanos, de novo em um contexto econômico, criticando o monopólio deste comércio. Ele pede ao rei que qualquer pessoa que more nas Índias tenha o direito de importar escravos negros, assim podendo efetivar seu desejo de povoação e exploração das terras sem o uso de indígenas.

O religioso, até este ponto, parece tratar com total indiferença a situação dos povos africanos escravizados, não sentindo a mesma revolta que o havia feito mudar toda direção de sua vida em relação aos povos nativos. Para muitos, isto pode parecer uma hipocrisia ou no mínimo uma contradição, mas é preciso lembrar-se de Las Casas como um homem do clero e o que isso representa.

Las Casas, como religioso de sua época, acredita nas guerras justas. No direito, como diz Sanchéz-Godoy, de "que se pode fazer guerra quando se trata de reinos cristão que tenham caído nas mãos dos pagão e dos hereges para recuperar as províncias que em outro tempo foram de jurisdição cristã." ${ }^{3}$ (2009, p.180). Isto influencia na sua percepção da legitimidade da escravização dos povos africanos, pois acreditava que estes eram muçulmanos que haviam invadido terras originalmente de domínio cristão.

Não só isso. Las Casas chega a descrever os povos africanos como "feras", bárbaros "Ausentes de razão, de costumes propriamente humanos e de tudo o que

\footnotetext{
${ }^{3}$ No original: "que se puede hacer guerra cuando se trata de reinos cristianos que han caído en manos de lo paganos o de los hereges para recuperar las provincias que en otro tiempo fueron jurisdicción cristiana.".
} 


\section{artigos}

\section{Las Casas e a escravidão na América Espanhola}

entre os homens se aceita por costume." " 4 (LAS CASAS, 2000 apud SANCHÉZ-GODOY, 2009) . Isto, segundo Sanchéz-Godoy, faz com que o dominicano interprete estes povos como servos por natureza, criaturas inferiores.

Interessante notar como este discurso de Las Casas parece muito com o que seu conhecido inimigo, Juan Ginés de Sepúlveda, usou em seu livro para justificar a exploração dos povos indígenas nas Índias. O próprio Las Casas descreve o acontecimento em seu livro Brevíssima Relação da Destruição das Índias:

“(...) Esse livro continha duas conclusões principais. Uma era que as guerras que foram feitas pelos espanhóis nas Índias, foram justas quanto a causa e ao direito em cujo nome foram movidas, sendo que, de modo geral, essas mesmas guerras podem e devem ser feitas. Outra conclusão era que os índios são obrigados a submeter-se para ser governados pelos espanhóis, como os menos sábios devem submeter-se aos mais prudentes e sábios; e que, se não querem submeter-se, os espanhóis podem mover-Ihes guerra." (Las Casas, 1984, p.116).

Em 1556, no seu primeiro volume da História das Indías, Las Casas diz estar arrependido quanto ao que disse no Memorial de Remédios sobre a escravidão africana, por não saber se aqueles que haviam sido capturados e traficados eram realmente frutos de guerras justas. É a primeira vez que mostra algum traço de discordância quanto a escravidão africana. Não como sistema, mas quanto ao modo como foi executada.

Muitos consideram este traço de empatia como reflexo de um encontro que Las Casas teve com o escravo Pedro Carmona. Após ter Ihe sido negada a herança que recebeu de seu finado dono e de ter tido sua esposa vendida e separada de si, o

\footnotetext{
${ }^{4}$ No original: bárbaros "faltos de razón, de costumbres propiamente humanas y de todo los que entre los hombres se acepta por costumbre".
} 


\section{artigos}

\section{Maria Alice Messias Conforti de Carvalho}

escravo decide seguir viagem para a Espanha, a fim de conseguir uma Audiência Real e falar diretamente com o rei. Baseado nas próprias anotações de Carmona sobre o ocorrido, há grandes chances de que Las Casas tenha Ihe oferecido transporte após ter ouvido sua história. Também pagou a fiança do escravo depois que este foi injustamente preso nas terras europeias.

O instinto de justiça de Las Casas parece então ter funcionado o suficiente para que este simpatizasse com a história de Pedro Carmona e passar a questionar a legitimidade da escravidão de certos africanos. No entanto, tal instinto não era forte o suficiente para que enxergasse problemas no sistema como um todo.

\section{LEGADO}

Que Las Casas é um dos maiores ícones da "libertação" indígena na América Latina é um fato incontestável. Em seu livro, Filosofia da Libertação, Enrique Dussel sugere que o frade é um antecessor da filosofia da libertação conhecida atualmente, citando uma fala sua em que alega que a dominação europeia sobre os povos nativos foi feita através do assassinato dos homens e pela servidão de mulheres e crianças, submetidas a dominação por meio de exploração sexual e assimilação compulsória da cultura europeia (DUSSEL, 1977, p.15 e 16).

No entanto, ao analisar as contribuições de Bartolomé de Las Casas para o debate sobre a escravidão no Novo Mundo, não só a indígena, como em geral, é na realidade difícil encontrar evidências de mudanças efetivas na situação dos escravizados que tenham sido causadas por seu mérito.

Em relação à escravidão africana, por exemplo, como foi dito anteriormente, há alguns teóricos como Herreros y Tordesillas, Charlevoix e Pauw que afirmam com 


\section{artigos}

\section{Las Casas e a escravidão na América Espanhola}

segurança que Las Casas foi grande responsável pela vinda de escravos ao Novo Mundo. Herreros y Tordesillas chegou até a insinuar que o frade usou de contatos que possuía para se certificar de que o processo realmente se realizasse (SANCHÉZGODOY, 2009, p.4). No entanto, outros teóricos já discordam desta concepção.

Em 1777, o escocês William Robertson, em seu livro "History of America", aponta que os portugueses já usavam a mão-de-obra escrava muito tempo antes de Las Casas fazer esta sugestão. O próprio Rei Fernando teria autorizado a importação de tais escravos por considerar "que eles são mais fortes que os índios" ${ }^{5}$ (SANCHÉZGODOY, 2009, p.7-8). Já em 1801, é publicada a "Apologia de Bartolomé de Las Casas" pelo Abate Grégoire, em que o autor contra argumenta as opiniões de que Las Casas estaria diretamente envolvido com a escravidão africana na América, usando de diversas fontes para mostrar que o envolvimento do frade neste acontecimento não poderia ser possível.

Em relação aos indígenas, pouco foi efetivado para que seu grande objetivo de emancipação indígena fosse cumprido. O que mais impossibilitou esta realização foi a contradição da liberdade dos povos nativos com sua fidelidade à Coroa espanhola e à Igreja. O dominicano não foi capaz de entender que a colonização e a doutrinação são sistemas de opressão por si próprios, que para funcionar precisam muitas vezes da violência exercida pelos encomenderos e oficiais espanhóis, que tanto repudiava.

Segundo Castro (2007, p.165), Las Casas também possuía o defeito de querer resolver conflitos menores, como discussões com encomenderos e simpatizantes, e deixar que isso o distraísse de finalizar seus maiores projetos.

No entanto, a falha de trazer real mudança para a população indígena não foi

\footnotetext{
${ }^{5}$ No original: "que ellos son más fuertes que los índios".
} 


\section{artigos}

\section{Maria Alice Messias Conforti de Carvalho}

apenas sua, mas um problema estrutural da Coroa de conseguir consolidar suas próprias leis quando estas não iam de acordo com as vontades dos encomenderos. A Lei de Burgos foi um exemplo disto. Segundo Castro (2007, p.164):

Em relação a toda a legislação em vigor nas Índias, existia uma relação próxima entre a complexidade da Lei e a ausência de mecanismos para reforçá-la, assim como a indisposição dos espanhóis morando nas colônias em obedecer. Quanto mais complexa e exigente a Lei, mais difícil era impô-la e traduzi-la em termos viáveis. (CASTRO, 2007, P.164) ${ }^{6}$

Muitos autores enxergam, contudo, uma influência de Las Casas para a criação das Leis Novas, uma das mais importantes legislações em relação aos direitos indígenas. Nela, determinou-se: o fim da escravidão indígena, a pena de morte para aqueles que levam índios livres para fazerem trabalhos de mineração, e, o mais importante, a criação de novas encomiendas - condição que foi retirada posteriormente, por medo de uma eventual rebelião (MÉNDEZ, 2009, p.39-45).

Em termos de repercussão, talvez a maior realização de Las Casas tenha sido a publicação de sua Brevísima relación de la destrucción de las Indias, que gerou enorme popularidade na Coroa, sobre a situação dos indígenas. Contudo, a obra foi sobretudo usada como arma política pela Coroa para desmoralizar os encomenderos, a fim de que eles obedecessem; e também por outros países, para denunciar a Espanha como um país cruel e fazer com que ela perdesse sua integridade internacionalmente (CASTRO, 2007, p.171 e 173).

No final, talvez uma das maiores contribuições de Las Casas para a emancipação indígena tenha sido os discípulos que deixou, como o Frei Domingos de

\footnotetext{
${ }^{6}$ No original: "In the case of all legislation governing the Indies, there existed a close relationship between the complexity of the Law and the absence of mechanisms to enforce it, as well as the unwillingness of Spaniards living $\mathrm{n}$ the colonies to obey. The more complex and demanding the Law, the more difficult was to enforce and translate into viable terms."
} 


\section{artigos}

\section{Las Casas e a escravidão na América Espanhola}

Santo Tomás, abolicionista que abraçou totalmente a causa, aprendendo o idioma e a cultura indígena e sugerindo o fim da imigração do Peru após o eventual desmonte das encomiendas, junto à volta dos líderes indígenas ao controle do país. A ele se atribui a citação “não é prata que se envia para a Espanha, é suor e sangue dos índios.".

\section{Conclusão}

Ao longo deste artigo foi exposta a maior questão quando se trata de Las Casas e sua relação com a escravidão na América Espanhola - contradição e conflito.

A contradição existente na sua dedicação de uma vida inteira quanto aos maus tratos a indígenas, ao mesmo tempo em que não pensava com o mesmo afinco nos escravos africanos. Ele não queria ou conseguia enxergá-los além de uma alternativa econômica para o fim da escravidão indígena. Quando considerava a humanidade daqueles indivíduos, era exatamente nesta escala. A injustiça da escravidão era vista apenas como ruim em casos de exceção, mas nunca como um problema sistemático (SANCHÉZ-GODOY, 2009, p. 67, 145, 146, 323 e 324).

A contradição também se fazia presente quando se percebe o fato de que Las Casas era fiel a diferentes setores que não trabalhavam em conjunto. Ele era um homem do clero, e queria acima de tudo a conversão dos nativos para o catolicismo e seus costumes. Mas ao mesmo tempo mantinha-se fiel à Coroa e aos reis, estabelecendo correspondência e acreditando na soberania do poder espanhol. E ainda estava do lado dos indígenas e queria ser visto por eles como seu protetor.

Isto fazia com que ele constantemente tivesse que se colocar no papel de conciliador e mediador destes três objetos de sua devoção, algo essencialmente 


\section{artigos}

\section{Maria Alice Messias Conforti de Carvalho}

impossível de se fazer. Isto é perceptível quando se analisa sua visão da extração dos bens do continente como algo possível de agradar aos interesses de todos, sua ignorância seletiva ao papel da Igreja no suicídio em massa de nativos e seu papel na redenção do cacique Enriquillo (CASTRO, 2007, p.67, 70, 71 e 93).

No entanto, o maior conflito de Las Casas está na imagem que se formou sobre ele. A construção do frade como um ícone da libertação indígena foi bastante construída por seus biógrafos, em sua maioria outros frades dominicanos, que exageravam narrativas de acontecimentos da vida de Las Casas e davam a elas um tom mitológico (CASTRO, 2007, p.160).

Na opinião de Castro (2007, p.160), esta construção de Las Casas como um salvador dos índios vem menos para exaltar o indivíduo em si e mais por uma demanda em se achar alguma figura que traga algum tipo de "positividade" para a história sangrenta da colonização das Américas. Como o autor coloca,

Na ausência de reais personagens heroicos, e a abundância de vilões e antiheróis durante a colisão Europeia com a America, Las Casas, quase por procedimento, surge como um dos personagens mais simpáticos, benevolentes e atraentes nascidos numa época de uma traumática gênesis da América. (CASTRO, 2007, p.160). ${ }^{7}$

Esta imagem de Las Casas como um herói além de seu tempo impede que se perceba que se tratava de um ser humano como qualquer outro, cheio de contradições; e também como um homem que era, sim, de seu tempo. Ele estava inserido em um contexto eclesiástico e imperialista, e isto implica nas características que se veem em suas atitudes.

\footnotetext{
${ }^{7}$ No original: "In the absence of true heroic personages, and the abundance of villains and antiheroes during the European collision with America, Las Casas, almost by default, emerges as one of the most sympathetic, benevolent, and attractive characters born at the time of the traumatic genesis of America."
} 


\section{artigos}

\section{Las Casas e a escravidão na América Espanhola}

Mesmo com todos esses defeitos, julga-se necessário lembrar que, mesmo assim, ele foi o encomendero cujas riquezas e status abdicou para advogar por aquilo que acreditava ser certo. Mesmo não tendo o impacto desejado (e que é creditado a ele) em termos de mudanças efetivas, foi ele quem trouxe a questão dos direitos indígenas para uma sociedade europeia até então muito ignorante sobre o assunto, e para uma Coroa cujo foco estava muito mais na questão da mão-de-obra e em seus conflitos internos com os encomenderos.

Sem o ativismo inicial de Las Casas, talvez tivesse levado ainda mais tempo para que ocorresse a criação das Leis Novas. E com certeza não teriam existido seus discípulos, que com ele aprenderam e foram capazes de ir além em termos ideológicos e de luta.

Las Casas trouxe o debate sobre os nativos americanos para um patamar de importância, e insistiu que fosse assim tratado até o momento de sua morte.

\section{Bibliografia}

BARNADAS, Joseph. A Igreja Católica na América espanhola colonial. In: BETHEL, Leslie (org.). América Latina colonial. v. 1. 1984, p. 521-552.

BATCHELDER, R., SANCHEZ, N. The encomienda and the optimizing imperialist: An interpretation of Spanish imperialism in the Americas. New York: Springer, 2013.

CASTRO, Daniel. Another Face of Empire: Bartolomé de Las Casas, Indigenous Rights, and Ecclesiastical Imperialism. Durnham: Duke University Press, 2007.

DUSSEL, Enrique. Filosofia da Libertação. São Paulo: Loyola; Unimep, 1977.

LAS CASAS, B.D. O paraíso perdido: Brevíssima relação da destruição das Índias. Porto Alegre: L\&PM, 1984.

MÉNDEZ, M. M. El trato al Indio y las Leyes Nuevas: una aproximación a un debate del siglo xvi. Espanha: Tiempo y Sociedad, 2009. 


\section{artigos}

Maria Alice Messias Conforti de Carvalho

RAMOS, Demetrio. Historia de La Colonizacion Espanhola em America. Madrid: Pegaso, 1947.

SANCHÉZ-GODOY, Rubén. Mercancía, Gentes Pacíficas y Plaga: Bartolomé de Las Casas y Las Orígenes Del Pensamiento Abolicionista Em El Atlántico Ibérico. Pittsburgh: Universidade de Pittsburgh, 2009. 